\title{
URBAN HERITAGE TOURISM KAWASAN JL. THAMRIN DENPASAR BALI
}

\author{
Oleh : Anak Agung Sagung Alit Widyastuty*)
}

\begin{abstract}
Abstrak
Pesatnya pertumbuhan perekonomian kota Denpasar sangat mempengaruhi percepatan perkembangan fisik kawasan kota yang ada. Hal ini sebanding dengan peningkatan kebutuhan ruang untuk menampung kegiatan akibat pertumbuhan ekonomi. Ruang Jl. Thamrin dan Jl. Dr. Soetomo memiliki potensi sebagai kawasan perdagangan pusat kota, dimana terdapat beberapa bangunan artefak bersejarah dengan arsitektur yang khas (Bali), sehingga terbuka kesempatan untuk memadukan aktifitas komersial dengan aktifitas pariwisata. Perkembangan yang terjadi dengan peruntukan yang beragam, masih meng-ekspresikan tema - tema berbeda yang belum mewujudkan unity in street design.

Metode penelitian yang digunakan dengan Pendekatan manajerial dalam studi pemerintahan kota yang lebih menfokuskan bagaimana rancang bangun organisasi pemerintah kota dalam menghadapi masalah - masalah perkotaan yang mendesak untuk dipecahkan. Serta Business plan yang akan dikembangkan pada kawasan koridor Jl. Thamrin dan Jl. Dr. Soetomo berdasarkan potensi - potensi yang ada, dengan menggunakan Urban heritage Tourism Development.

Bentuk dasar dari tourism yang terdapat di kawasan luas, daerah dan kota kecil sebagai perluasan dari dasar fungsi urban, berupa peraturan - peraturan kota sebagai pusat budaya ; atau dalam syarat fasilitas urban untuk penduduk asli ( berupa taman hiburan, taman - taman atau pasar / pertokoan ) yang juga dapat menarik wisatawan. Urban Tourism dapat meningkatkan pendapatan daerah, lapangan kerja dan pajak untuk kota Denpasar, dengan urban tourism dapat mengisi kekosongan itu. Kota - kota di Indonesia khususnya di kota Denpasar dimana perkembangan industri dan perdagangan berkembang cepat, urban tourism dapat menyediakan keperluan hasil kerajinan lokal untuk menunjang infrastruktur dan membawa masukan pendapatan bagi kota.
\end{abstract}

\section{Kata Kunci : Urban Heritage Tourism, Konsep Pariwisata,United In Street Design}

\section{Pendahuluan \\ Latar Belakang}

URBAN Heritage Tourism merupakan sebuah konsep pariwisata yang akhir-akhir ini banyak dikembangkan di kota-kota besar di seluruh penjuru dunia. Sebuah konsep pariwisata yang sebenarnya sederhana dengan memanfaatkan lingkungan binaan maupun alam yang dimiliki oleh sebuah kota, yang memiliki nilai historis tersendiri. Para penikmat dan pemerhatinya diajak untuk mengapresiasi serta menginterpretasi objek-objek yang diamati. Dengan demikian, selain berfungsi sebagai sarana pendidikan dan rekreasi masyarakat, aktivitas ini sekaligus pula sebagai sarana pelestari dari kekayaan kota itu sendiri.

Objek yang diamati pada urban heritage tourism bisa bermacam-macam, baik benda (mati atau hidup) maupun juga aktivitas. Umumnya, benda-benda seperti situs, monumen, serta bangunan-bangunan bersejarah memiliki posisi yang penting dalam wisata jenis ini. Kota-kota yang berusia tua melebihi ratusan tahun memiliki banyak bangunan yang merupakan saksi bisu dari perkembangan lingkungannya, potret dari kejadian-kejadian masa lampau yang pernah terjadi di sekelilingnya. Bangunan-bangunan tersebut kemudian menjadi bukti sejarah yang konkret, yang mendukung buku-buku sejarah yang ditulis bertahun-tahun kemudian.

Selama ini, disadari ataupun tidak, Kota Denpasar memiliki potensi yang cukup besar untuk pengembangan urban heritage tourism. Sebagai kota dengan sejarah yang cukup panjang, Kota Denpasar memiliki koleksi bangunan-bangunan tua berupa Pura dan Bangunan kuna berarsitektur Bali yang dibangun pada masa kejayaan Kerajaan Badung dalam jumlah yang relatif besar.

Dari sekian banyak kawasan bersejarah di kota Denpasar, salah satunya adalah kawasan ruas jl. Thamrin dan Jl. Dr. Soetomo. Kawasan ini memiliki potensi sebagai kawasan perdagangan di pusat kota, dimana terdapat beberapa bangunan artefak bersejarah dengan arsitektur yang khas (Bali), sehingga terbuka kesempatan untuk memadukan aktifitas komersial dengan aktifitas pariwisata yang bertemakan urban heritage tourism. Perkembangan yang terjadi dengan peruntukan yang 
beragam, masih mengekspresikan tema - tema berbeda yang belum mewujudkan Unity in Street Design (Kesatuan desain deretan bangunan - bangunan di tepi jalan).

\section{*) Dosen Perencanaan Wilayah \& Kota (PWK) Universitas PGRI Adi Buana - Surabaya.}

\section{Permasalahan}

Tidak adanya suatu mediator yang dapat menyatukan beberapa poternsi yang ada di kawasan, sehingga menjadi kesatuan tema yang menarik dan berkesinambungan dengan konsep urban heritage tourism.

\section{Maksud, Tujuan dan Sasaran}

\section{Maksud}

Penelitian ini dimaksudkan untuk membentuk dan menyelaraskan ruang yang telah ada dengan mengembangkan potensi kawasan dan tetap mempertahankan ruang - ruang fungsional untuk kepentingan publik dan khasanah budaya Bali.

\section{Tujuan :}

1. Mempelajari dan mengidentifikasi elemen - elemen kota yang potensial untuk pengembangan kawasan.

2. Mengembangkan fungsi ruang kota dengan memperhatikan unsur - unsur pariwisata dan variasi komponen kota

3. Membuat panduan (guidelines) Urban herritage tourism untuk pengembangan kawasan kota Denpasar Khususnya kawasan ruas jl. Thamrin dan jl. Dr. Sutomo.

\section{Sasaran}

1. Memanfaatkan elemen - elemen kota yang berpotensi dan bernilai sejarah untuk dikonservasi

2. Menyelaraskan lingkungan terdahap potensi yang ada

3. sebagai dokumen guidelines urban heritage tourism

\section{Tinjauan Pustaka \\ Kebijaksanaan Pengendalian Pusat Kota}

Sebagai akibat laju perkembangan potensi ekonomi dan pariwisata yang sangat menonjol, telah menimbulkan kecenderungan perubahan fungsi dan wajah kawasan pusat kota, terutama terjadi pada kawasan yang memiliki potensi ekonomi yang strategis. Dapat dipahami bahwa keberadaan tanah di pusat kota berkembang nilainya menjadi semakin tinggi dan memiliki kecenderungan mengarah ke fungsi - fungsi komersial. Dalam mengantisipasi hal tersebut perlu pengendalian pemanfaatan lahan secara efektif dan efisien.
Atas dasar potensi yang dimiliki dan permasalahan yang dihadapi Pemerintah Daerah kotamadya Denpasar menempuh kebijaksanaan tata ruang kota sebagai berikut :

1. Pengembangan fisik kota Denpasar khusunya areal terbangun: dilakukan dengan memperluas areal baru secara selektif sesuai dengan kebutuhan dan poternsi yang ada serta didukung dengan tata ruang yang lebih rinci.

2. Perkembangan fisik areal terbangun kota Denpasar, hampir ke semua arah dengan prioritas pengembangan pada lahan - lahan yang tidak produktif dan lahan tidur, serta dengan tetap mempertimbangkan pemandangan alam yang abik, jalur hijau, jarak/radius larangan membangun terhadap kawasan khusus dan lahan yang perlu dipertahankan.

3. Menjaga kelestarian dan keseimbangan lingkungan dengan tetap berorientasi kepada standar optimasi pemanfaatan ruang dengan mempertahankan proporsi maksimum 40\% kawasan terbangun dengan minimum $60 \%$ kawasan tidak terbangun, serta menekan sekecil - kecilnya kegiatan yang mencemari lingkungan.

4. Pada pusat kota dan pusat - pusat pelayanan lainnya di dalam kota dapat dilakukan pengembangan secara intensif (bangunan bertingkat) yang dibatasi oleh peraturan daerah, awig-awig serta norma - norma adat setempat yang berlaku.

5. Mengarahkan perkembangan kegiatan kota yang menuju kepada perpaduan antara kegiatan dasar yang terpusat di ;lokasi - lokasi tertentu di satu pihak dan terbentuknya kawasan - kawasan khusus sebagai pusat orientasi penduduk di pihak lainnya.

6. Dalam kaitannya dengan fungsi utama suatu kota, maka Denpasar memiliki fungsi dasar dan fungsi penunjang yaitu :

a. Fungsi dasar sebagai : pusat perdagangan, pusat industri, pusat transportasi, pusat aktivitas pariwisata dan sebagai pusat aktivitas jasa regional

b. Fungsi penunjang sebagai : pusat pemerintahan, pusat pendidikan, pusat pelayanan kesehtan, pusat utilitas terutama telekomunikasi dan listrik serta sebagai pusat hankam.

\section{Program Pengembangan Pusat Kota}

Untuk meningkatkan kesejahteraan penduduk dengan tetap memperhatikan daya dukung lingkungan baik lahan/daratan, air dan kelautan serta udara perlu adanya suatu strategi pengelolaan yang baik, antara lain strategi 
pengelolaan lahan perkotaan. Secara konsepsial, strategi penelolaan lahan perkotaan didekati melalui model :

1. Model pendekatan melalui pengembangan perundang - undangan yang berlaku, hal ini dituangkan dalam bentk kebijaksanaan pengembangan lahan (land development), melalui pengefektifan peraturan perundang - undangan (legal aspect) yang sudah ada dan kemungkinan pengembangannya untuk lahan perkotaan.

2. Model pendekatan pola kebijaksanaan lahan perkotaan, dalam bentuk:

a. Kebijaksanaan pengaturan lahan (urban land use planning) yang didasarkan pada Rencana Tata Ruang Kota, nilai lahan, daya dukung dan fungsi diatasnya.

b. Kebijaksanaan pengelolaan Lahan kota (urban land management) termasuk penyediaan lahan, baik yang bersifat konvensional maupun inkonvensional (seperti land banking, land rent, land consolidation, guide land development), efektifitas perpajakan,

kompetensi lahan serta pengendalian dan pengawasan pengembangan lahan secara terpadu.

c. Kebijaksanaan Sistem Informasi (urban lad information system) yang teorganisir untuk emnunjang kebutuhan perencanaan pemanfaatan, penggunaan, pengembangan, pengendalian dan penetapan status lahan.

3. Model pendekatan melalui teknis pengadaan dan penguasaan lahan dalam bentuk :

a. Kebijaksanaan pengadaan lahan dalam bentuk penguasaan laha, prosedur pengalihan hak, status kepemilikan, dalam hubungannya dengan peran pemerintah, swasta dan masyrakat sebagai upaya peningkatan efektivitas dan efisien pemanfaatan lahan perkotaan.

b. Peningkatan kesadaran dan partisipasi masyarakat dalam pembangunan melalui system informasi, pendekatan dan penyuluhan secara terpadu dan berkesinambungan.
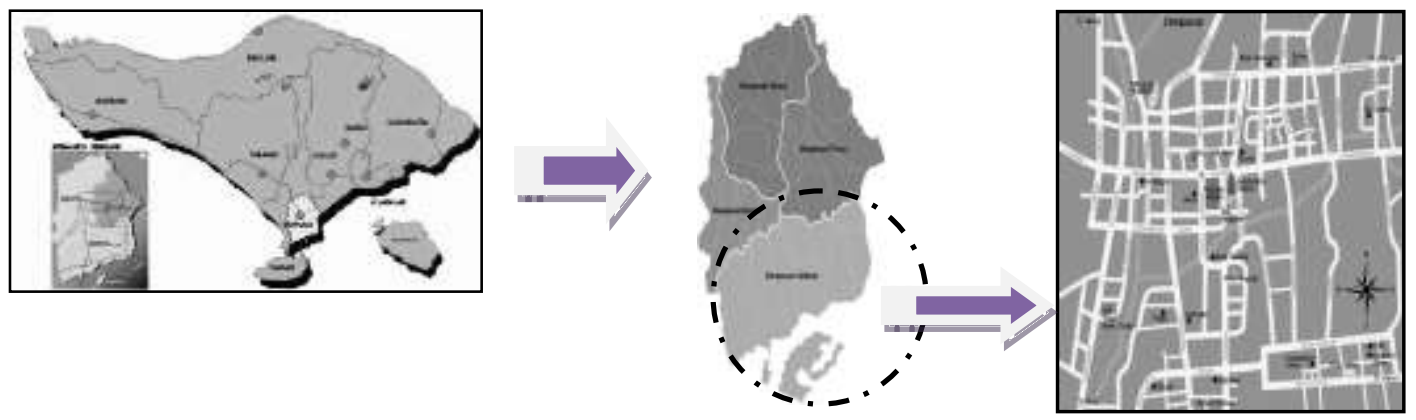

Gambar II. 1

Peta kawasan penelitian

\section{Filosofis Penataan Ruang Tradisional Bali}

Melalui pemahaman keselarasan hubungan antara Bhuana Agung dan Bhuana Alit yang dibedakan atas Purusha/atma/jiwa dan prakerti/raga. Pendekatan tata ruang diturunkan dari filosofi tersebut yang kemudian memberi pengertian adanya jiwa sebagai bentuk konsep tri hita karana yang terdiri dari unsur - unsur jiwa, tenaga dan fisik. Serta adanya prakerti dalam penataan ruang sebagai perwujudan bentuk konsep tri angga yaitu utama angga/sacral, madya angga/netral dan nista angga/profal.

Teori arsitektur bali, arsitektur tradisional Bali dalam hal ini yang terkait dengan konsep tata ruang kawasan puri adalah :
1. Konsep / pola Catus Patha atau sering disebut dengan konsep pempatan agung, merupakan pola tatanan massa sesuai dengan arah mata angin (catur loka phala) merupakan persimpangan segi empat, masing - masing arah memiliki makna tersendiri, yaitu :

a. Pempatan agung (titik pusat) sebagai pusat lingkungan.

b. Arah timur laut (kaja kangin) sebagai tempat yang utama untuk puri, Pura desa atau Pura Puseh.

c. Arah tenggara (kelod kangin) sebagai tempat yang baik untuk lapangan terbuka

d. Arah barat laut (kaja kauh) sebagai tempat yang baik untuk wantilan / gedug serba guna 
e. Arah barat daya (kelod kauh) sebagai tempat yang baik untuk pasar.

2. Konsep Sanga Mandala, yaitu tata nilai rumah tinggal berdasarkan sembilan penjuru mata angin sesuai dengan hirarjhi ruang nista, madya, dan utama.

3. Konsep asta bumi dan astakosala/kosali yang dilatarbelakangi oleh :

a. Filosofi arsitektur tradisional bali yaitu Tri Hita Karana

b. Konsep proporsi bangunan Tri Angga (kepala, badan, kaki)

c. Konsep Tri Loka (Bhur/bawah, Bwah/ tengah, Swah/atas)

d. Konsep Hirarkhi tata nilai (utama, madya, nista)

\section{Metode Penelitian}

\section{Pendekatan Manajerial}

Pendekatan manajerial dalam studi pemerintahan kota lebih menfokuskan bagaimana rancang bangun organisasi pemerintah kota dalam menghadapi masalah masalah perkotaan yang mendesak untuk dipecahkan. Pendekatan ini cenderung mengabaikan struktur organisasi formal yang diatur oleh undang - undang pemerintah lokal, dan lebih bagaimana peran dan fungsi yang dapat dimainkan oleh pemerintah kota yang menjadi salah satu aktor dalam pembangunan kota.

\section{Business Plan (Rencana Bisnis) sehubungan dengan pengembangan Proyek. \\ Business plan yang akan} dikembangkan pada kawasan koridor Jl. Thamrin dan Jl. Dr. Soetomo berdasarkan potensi - potensi yang ada, dengan menggunakan Urban heritage Tourism Development.

\section{Tinjauan Kawasan penelitian}

IV.1 Tinjauan kotamadya Denpasar

IV.1.1 Aspek Geografi dan administrasi

Denpasar sebagai ibukota Propinsi Bali, secara geografis terletak antara 08"35"31 - 08"44"49 LS dan 115"10"23 - 115"16"27 BT. Meliputi tiga kecamatan yaitu :

1. Kecamatan Denpasar Barat

2. Kecamatan Denpasar Timur

3. Kecamatan Denpasar Selatan

Dengan luas wilayah adalah 123,98 $\mathrm{Km}^{2}$ terletak pada ketinggian antara 00-75 m diatas permukaan laut serta suhu rata - rata tercatat antara $23,5-28^{\circ} \mathrm{C}$. (RTRW Kotamadya Denpasar tahun 1994 - 2004).

Secara administrasi Denpasar terdiri atas 43 desa dinas/keluarahan dan 200 banjar dinas, sedangkan secara adat terdiri atas 35 desa adat dan 341 banjar adat. Terdapat 8 tukad (sungai) yang melintas diwilayah Denpasar, tiga diantaranya yang cukup besar adalah :

1. Tukad Ayung

2. Tukad Badung

3. Tukad Mati (RTRW Kotamadya Denpasar tahun 1994 - 2004)

\section{IV.1.2 Aspek Sosial Budaya dan Ekonomi IV.1.2.1 Kependudukan}

Jumlah penduduk kotamadya Denpasar pada akhir tahun 1996 sejumlah 371.424 jiwa, dengan rata - rata kepadatan penduduk 2.996 orang $/ \mathrm{km}^{2}$. kecenderungan pertambahan penduduk berdasarkan perkembangan penduduk dalam lima tahun terakhir didapatkan laju pertumbuhan penduduk adalah $2,19 \%$ pertahun. Sehingga sampai dengan tahun 2004 diperkirakan jumlah penduduk akan mencapai 425.108 jiwa dengan rincian masing - masing kecamatan adalah :

1. Kecamatan Denpasar Barat : 184.712 Jiwa

2. Kecamatan Denpasar Timur : 104.278 Jiwa

3. Kecamatan Denpasar Selatan : 100.118 Jiwa

\section{IV.1.2.2 Budaya Setempat}

Pemahaman terdahap adapt istiadat masyarakat Bali khususnya di kota Denpasar dalam kaitan dengan pembangunan kota harus ditinjau dari sudut yang lebih luas yaitu kebudayaan dan keagamaan. Kedua hal tersebut saling terintegrasi dan meupakan landasan bagi kehidupan masyarakatnya. Secara garis besar pemahaman dapat ditinjau atas dua aspek, yaitu pemahaman terhadap nilai ritual dan natural serta pemahaman terhadap system kemasyarakatan.

\section{IV.2 Tinjauan Kawasan Kajian \\ IV.2.1 Lokasi Kawasan Kajian}

Wilayah kajian berada pada kawasan perdangan pusat kota kotamadya Denpasar, yang terletak di Jl. Thamrin. Wilayah ini merupakan kawasan perdangangan dan jasa, sekaligus merupakan kawasan transisi antara pusat perdagangan kota Denpasar dengan daerah yang sebagian besar merupakan permukiman. Wilayah ini penting untuk ditingkatkan kualitas Visual, fungsional dan lingkungannya melalui suatu panduan penataan, karena merupakan kawasan perdagangan kota lama yang saat ini hanya menjadi daerah lintasan saja. Sehingga untuk menetapkan kawasan ini sebagai pusat perdagangan sub kawasan pusat kota kotamadya Denpasar. 


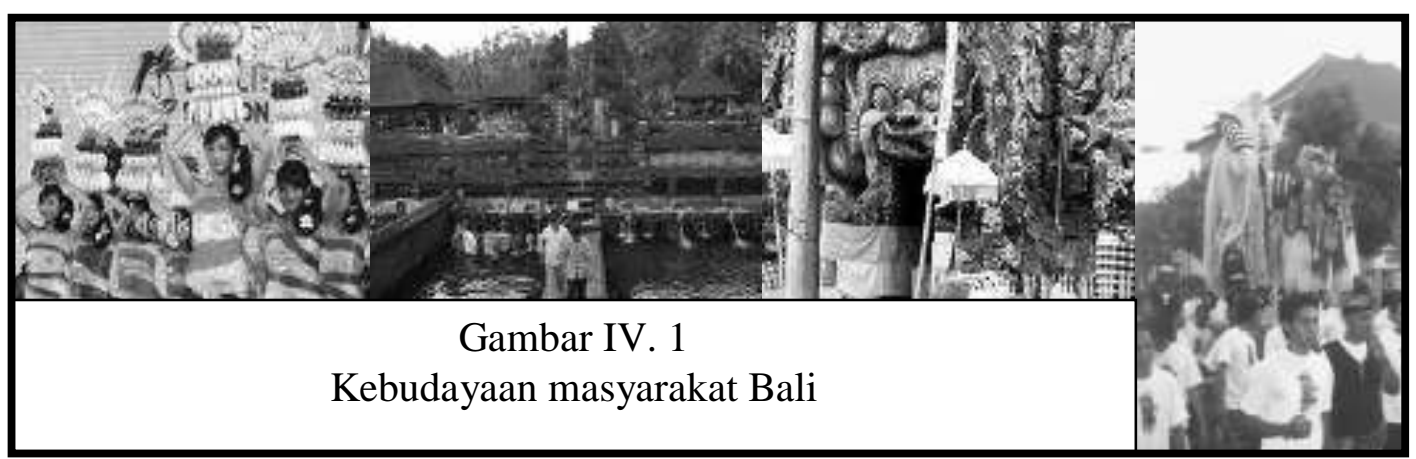

\section{IV.2.2 Potensi Kawasan Kajian}

1. Potensi Fisik.

a. Kawasan ini merupakan kawasan bisnis (pertokoan, jasa dan perbankan).

b. Ruas Jl. Thamrin menjadi kawasan wisata kota yang memiliki bangunan bersejarah seperti : Puri Pemecutan, Puri Kangin, dan Puri Kawan.

c. Jl. Thamrin mmiliki alur satu arah menuju ke Jl. Gajah Mada sebagai central bussiness district dan menuju Jl. Wahidin untuk ke poros Jl. Gunung Agung dan keluar kota.

d. Jalur ini memiliki berbagai fungsi bangunan pada kanan kiri jalan dan didominasi oleh kawasan permukiman.

\section{Potensi Non Fisik.}

a. Puri - puri dan Pura - pura besar tersebut merupakan pusat kebudayaan yang memiliki nilai sejarah yang mengakar sangat kuat diseluruh lapisan masyarakat kota Denpasar, sekaligus merupakan sentral kekuasaan aristokrasi bangsawan Bali pra Kolonial. Kekuasaan ini masih tetap terbuna hingga saat ini, sebagai hubungan paton klien dalam struktur sosial tradisional.

b. Terdapatnya bangunan bangunan artefak dengan penampilan arsitektur khas Bali di kawasan perdagangan ini. Akan dapat menjadi tujuan wisata yang memadukan kegiatan komersial dan wisata belanja.

\section{IV.2.3 Karakteristik Khas bangunan Kawasan Kajian}

Kawasan kajian yang meliputi Jl. Thamrin mengalami pertumbuhan dan perkembangan yang sejalan dengan sejarah perkembangan kota Denpasar. Bahkan sebagai kawasan kota lama Denpasar, kawasan ini menjadi barometer dari tingkat kemajuan pembangunan di kota Denpasar. Adanya beragam fungsi kegiatan pada kawasan, telah menampilkan ekspresi tema tema yang berbeda yang belum mewujudkan adanya suatu Unity in Street Design.

Namun dengan menonjolnya fungsi sebagai kawasan perdagangan pusat kota, dimana terdapat bangunan artefak sejarah dan bermakna sosial budaya yang tinggi, sangat terbuka kesempatan untuk memadukan aktifitas komersial dengan aktifitas pariwisata. Keberadaan puri Pemecutan, yang dalam proses perwujudannya lebih menitikberatkan pada makna ritual dan social culture, nampak memberikan warna dan nuansa lain di kawasan.

\section{IV.2.4 Kondisi Bangunan Jalan Thamrin}

Penataan bangunan di jalan Thamrin dilihat dari dominasi fungsi, maka lingkungan koridor jalan Thamrin meruapakan kawasan perdagangan. Hal ini terlihat dari deretan bangunan fungsi pertokoan yang terletak disebelah timur dan barat serta ditegaskan dengan adanya satu bangunan pusat perbelanjaar Lokitasari dalam wujud massa monolit.

1. Segmen Barat Jalan Thamrin. a. Fungsi Bangunan 
Secara sekilas dengan melihat dominasi fungsi adalah kawasan perdagangan. Namun ditinjau secara rinci dan terpisah deretan bangunan - bangunan didalam kawasan perdagangan tercecer beberapa fungsi lain yang berperan dalam pembentuk imaji kawasan, khususnya terhadap pembentukan ruang luar. Hal ini terlihat adanya fungsi penginapan, kantor pengadaian, dan beberapa bank.

\section{b. Fasade bangunan}

Fasade banguna pada deretan pertokoan sangat bervariasi dalam penggunaan bahan penutup (selubung bangunan). Permainan bidang tektur, warna dan jenis jenis reklame yang menempel. Satu blok bangunan monolit dari pertokoan Lokasari fasadenya terwujud dari susunan stand penjualan dan dengan balustrade beton yang dibatasi pipa dengan perletakan tangga yang sentries mengarah kedepan.

\section{c. Garis Sempadan}

Melihat konfigurasi deretan bangunan secara keseluruhan sempadan yang terjadi adalah mendekati keragaman. Satu sisi bangunan kantor penggadaian yang terletak disela - sela pertokoan memiliki tata letak tersendiri dengan memundurkan GSB yang menjadikan suatu garis muka bangunan (GMB) terhadap deretan pertokoan. Bangunan lainnya yang berperan sebagai GSB, adalah bangunan perbelanjaan/pertokoan Lokitasari. Dilihat dari penataan tangganya GSB bangunan Lokitasari kedepan dekat dengan trotoar.

\section{d. Ketinggian Bangunan}

Konfigurasi ketinggian bangunan pada deretan pertokoan tersebut adalah bervariasi antara dua sampai empat lantai. Bangunan lainnya yang satu lantai adalah penginapan yang teletak diujung selatan jalan (disudut barat laut perempatan jalan) di belakang (sebelah barat) pengiapan terdapat bangunan lantai lima yang terlihat dari jalan Thamrin.
Bangunan pertokoan Lokitasari, mempunyai ketinggian 3 lantai dengan fungsi sebagai pbioskop pada lantai paling atas.

2. Segmen Timur Jalan Thamrin.

Pada segmen ini memiliki puri yang disebut dengan puri Pemecutan dengan kekhasan / ciri penonjolan tempat suci berupa Meru dan adanya bangunan penginapannya yang berlantai tiga.

\section{a. Fungsi Bangunan}

Fungsi bangunan di segmen timur jalan Thamrin secara keseluruhan memiliki fungsi - fungsi yang sama dengan deretan disebelah barat. Berupa deretan pertokoan, penginapan/hotel. Bedanya hanya terdapat adanya kantor penggadaian disebelah barat sedangkan disebelah timur memiliki kelebihan fungsi yaitu adanya bale banjar puri serta kelompok hunian yang tidak ekspose/berorientasi ke jalan. Hal ini terlihat dari pencapaian hunian yang entracenya dari halaman hotel yang berada disebelah selatan, dan lahan yang berhadapan langsung dengan jalan Thamrin dibatasi dengan pagar tinggi yang Telajakannya berfungsi untuk jalur hijau.

\section{b. Fasade bangunan}

Dengan berbagai fungsi bangunan yang terdapat pada segmen jalan maka fasadenya pun mengalami berbagai ciri dan karakter sebagai perwujudan dari berbagai jenis material penutup, tektur dan warna serta perbedaan konfigurasi bentuk. Fasade memiliki cirinya masing - masing seperti halnya fasade bangunan puri yang berarsitektur tradisional Bali, sedangkan untuk bangunan pertokoan, perkatoran jasa dan bank berarsitektur modern dengan sedikit penambahan ornamen tradisional Bali.

\section{c. Ketinggian bangunan}

Rangkaian bangunan yang berderet disebelah timur jalan, memiliki ketinggian yang bervariasi mulai dari ketinggi satu lantai sampailima lantai. Yang 
termasuk ketinggian saru lantai adlah bangunan rumah tinggal, termasuk puri yang ada di zona dalam. Hdan lainnya memiliki ketinggian satu lantai adlah pertokoan di pertigaan jalan yang menuju pasar Kumbasari.

\section{d. Garis Sempadan Bangunan}

Pada kawasan ini garis sempadan bangunannya memiliki keragaman. Terlihat dari lurusnya muka bangunan deretan pertokoan.

\section{IV.2.5 Papan Reklame / Iklan}

Papan iklan/reklame sebagai eleven visual yang didesain dengan baik dan sesuai dengan tema kawasan fungsional, dapat memperkuat karakter arsitektur urban dari statu kawasan. Penataan papan reklame yang ada di kawasan studi tidak memiliki suatu ketentuan, sehingga penempatan - penempatannya yang bebas timbal persaingan saling menonjolkan diri yang akhirnya mengakibatkan penurunan kualitas visual. Seperti halnya penempatan reklame pada setiap pertokoan jalan Thamrin). penempatan reklame sebagai eleven cisual yang menarik diwujudkan dari :

a. Pola penataan ketinggian dengan keragaman atau variasi irama.

b. Pola penataan jarak antar reklame

c. Pola bentuk dan posisi penataan (vertikal jalan, searah jalan, dengan sudut kemiringan, bergerak/statis). Khususnya yang terkait dengan gerak dilakukan dengan sistem penyinaran untuk malam hari.

d. Pola ukuran/dimensi. Hal ini sangat terkait dengan :

1) Jarak pandang

2) Kecepatan pandang.

\section{Analisis Kawasan Kajian}

Dalam GBHN 1993 telah menetapkan bahwa Pembanguna Kepariwisataan dilanjutkan dan ditingkatkan dengan mengembangkan dan mendayagunakan sumber dan potensi kepariwisataan Nasional menjadi kegiatan Ekonomi yang dapat dihandalkan, antara lain sebagai berikut :

1. Peningkatan Pariwisata menjadi Sektor Andalan :

Menggalakan kegiatan ekonomi, sehingga :

a. Lapangan kerja
b. Pendapatan Masyarakat, Daerah dan Negara
c. Penerimaan Devisa
Meningkat melalui upaya
pengembangan dan pendayagunaan berbagai potensi kepariwisataan Nasional.

2. Peningkatan Pariwisata harus di jaga.
a. Tetap terpeliharanya kepribadian bangsa, kelestarian fungsi dan mutu lingkungan hidup.
b. Ditata secara menyeluruh, terpadu dengan melibatkan sektor lain yang menunjang / menguntungkan. terkait dalam satu keutuhan usaha kepariwisataan yang saling

3. Pengembangan Pariwisata Nusantara dilaksanakan

a. Sejalan dengan upaya memupuk rasa cinta tanah air dan bangsa, menanamkan jiwa semangat dan nilai - nilai luhur bangsa dan memperkukuh persatuan / kesatuan nasional terutama dalam bentuk penggalakan pariwisata remaja dan pemuda dengan kemudahan pelayanan pariwisata.

b. Daya tarik Indonesia ditingkatkan melalui pemeliharaan benda dan khasanah bersejarah, didukung promosi yang memikat.

4. Upaya mengembangkan obyek dan daya tarik wisata serta kegiatan promosi dan pemasarannya di dalam maupun di luar negeri.

Terus tingkatkan secara terencana, terarah, dan efektif antara lain memanfaatkan kerja sama dan global guna meningkatkan hubungan antar bangsa.

5. Pendidikan dan Latihan pariwisata makin ditingkatkan melalui penyediaan sarana dan prasarana yang baik, dalam rangka meningkatkan kemampuan untuk menjamin mutu dan kelancaran pelayanan serta penyelenggaraan pariwisata.

6. Kesadaran dan peran aktif Masyarakat perlu ditingkatkan melalui :

a. Penyuluhan dan pembinaan kelompok : Seni budaya dan Industri kerajinan.

b. Meningkatkan kualitas Budaya dan Daya tarik Pariwisata dengan tetap menjaga : Nilai - nilai agama, citra kepribadian bangsa 
dan harkat serta martabat bangsa.

Harus dicegah hal - hal yang merugikan masyarakat dan kelestarian kehidupan Budaya.

\section{Suatu rencana pariwisata setidaknya} memuat lima komponen utama, yaitu :

1. Komponen manusia, orangnya, baik manusia lokal maupun para pariwisata sendiri. Adalah penting untuk melibatkan warga kota dalam pengembangan pariwisata itu sehingga mereka juga dapat memahami manfaat dari pariwisata, tahu bagaimana seharusnya menyapa dan berkomunikasi dengan wisatawan mancanegara, bagaimana memberi reaksi terhadap kemungkinan adanya penestrasi kebudayaan lain, dll.

2. Komponen atraksi dan peristiwa, adanya peristiwa dan atraksi, ada wisatawan. Mereka mengadakan perjalanan, menginap di hotel, makan direstoran, membeli souvenir dsb.

3. Komponen servis dan fasilitas. Komponen ini tidak kalah pentingnya dari komponen atraksi dan peristiwa. Sungguhpun atraksi itu dapat memberi kepuasan tetapi apabila servis dan fasilitas yang berkualitas tidak mendukung, maka wisatawan itu akan menggerutu atau ingin cepat meninggalkan kawasan tersebut.

4. Komponen Transportasi. Justru yang memegang peranan penting dalam mengantar wisatawan menyaksikan atraksi dan peristiwa. Jaringan transportasi dalam kota dan dari kota ke obyek tourisme di luar kota hendaknya merupakan suatu mata rantai yang terkoordinir, nyaman dan menyenangkan.

5. Komponen Informasi dan Petunjuk arah dan dimana. Seorang wisatawan haruslah dianggap sebagai orang yang buta mengenai kota, tidak mengetahui apa, dimana dan bagaimana. Sebab itu mereka perlu diberi dan disediakan informasi yang memudahkan mereka untuk mencari dan menuju ke tempat yang dipilih untuk disaksikan.

\section{V.1 Program dan strategi}

Bentuk dasar dari tourism yang terdapat di kawasan luas, daerah dan kota kecil sebagai perluasan dari dasar fungsi urban, berupa peraturan - peraturan kota sebagai pusat budaya ; atau dalam syarat fasilitas urban untuk penduduk asli ( berupa taman hiburan, taman - taman atau pasar / pertokoan) yang juga dapat menarik wisatawan.

Urban Tourism dapat meningkatkan pendapatan daerah, lapangan kerja dan pajak untuk kota Denpasar ; dimana setiap kota pasti mengalami transisi ekonomi seperti yang terjadi di negara Amerika Serikat dimana pusat kota lama kehilangan pabrik tradisional mereka dan fungsi ekonomi, dengan urban tourism dapat mengisi kekosongan itu. Kota kota di Indonesia khususnya di kota Denpasar dimana perkembangan industri dan perdagangan berkembang cepat, urban tourism dapat menyediakan keperluan hasil kerajinan lokal untuk menunjang infrastruktur dan membawa masukan pendapatan bagi kota.

\section{V.2 Strategi Urban Tourism :}

1. Mengabungkan antara lahan comprehensive dengan rencana transportasi.

Dengan membedakan antara bangunan, pedestrian ways, transportasi tradicional (dokar) dan kendaraan bermotor (mobil dan sepeda motor). Sehingga dapat memberikan rasa aman dan nyaman bagi para pariwisata yang ingin berjalan kaki maupun yang memakai transportasi tradicional (Dokar).

2. Menetapkan tujuan dan sasaran yang akan dijadikan urban tourism.

Dengan adanya potensi Jl. Thamrin sebagai pusat perdagangan (souvenir khas pulau Bali) yang berdampingan dengan kawasan pusat budaya (Puri Pemecutan dan artefak - artefak lain) Sangay menunjang kawasan sebagai urban tourism.

3. Menyiapkan fasilitas dan atraksi untuk para pariwisata

Dengan dibangunnya hotel di Puri Pemecutan dan adanya kegiatan kesenian (tari tarian, gamelan dan lain - lain), juga atraksi yang diberikan oleh pertokoan di sepanjang koridor Jl. Thamrin

4. Menganalisa pemasaran dan penegakan target pasar yang dihubungkan dengan atraksi yang bervariasi.

5. Penilaian terhadap hubungan antar daerah kawasan yang berdampingan. 
6. Apa yang harus di angkat atau atraksi baru apa yang harus ditambahkan untuk kawasan urban taourism agar tampilannya lebih menarik tanpa mengabaikan nilai - nilai agama, dan citra kepribadian masyarakat sekitar kawasan.

7. Memperhatikan dampak yang dihasilkan. Memperhatikan secara keseluruhan kualitas dan charakter kota yang meliputi : style arsitektur tradicional bali, taman dan lapangan terbuka, landscaping, pemandangan alam, tingkat keramaian lalu lintas, kualitas lingkungan, keamanan, masalah - masalah servis pelayanan.

\section{V.3 Prinsip Perencanaan dalam pengem-} bangan urban tourism adalah :

1. Lokasi hotel diusahakan dekat dengan lokasi atraksi, atau tersedianya transportasi yang mudah dan efisien.

2. Tersedianya pemasaran hotel akomodasi.

3. Pedestrian ways untuk wisatawan.

4. Menggunakan Publio control untuk mengatur perkembangan yang mendukung tampilan bangunan - bangunan kuno bersejarah, dan ruang terbuka.

5. Menggunakan kawasan bersejarah jira memungkinkan, seperti Puri Pemecutan dimana di dalamnya terdapat hotel penginapan untuk para wisatawan.

6. Mendorong tatanan atraksi untuk wisatawan.

7. Mengontrol aliran wisatawan untuk mencegah penurunan kualitas lingkungan.

8. Pembongkaran fasilitas wisata jika dirasakan keberadaannya mengganggu kegiatan wisata.

9. Tersedianya infrastruktur yang memadai.

Selain strategi - strategi di atas ada beberapa kegiatan manajemen yang dapat mendukung pengembangan pariwisata, yaitu :

1. Calender of Events : Sasaran dari kalender peristiwa ialah merencanakan pelayanan yang memuaskan bagi pariwisata tetapi di balik itu ada hasrat untuk merogoh saku wisatawan sebanyak mungkin. Seseorang wisatawan yang merasa Sangat puas dengan atraksi, servis dan fasilitas tidak tanggung - tanggung mengeluarkan biaya yang sepadan.

2. Cultural Events : Kota Denpasar adalah konsentrasi dari pertemuan lintas budaya. Ini merupakan peluang yang harus ditangkap dan dimanfaatkan. Pemerintah kota hendaknya me- rangsang, melakukan koordinasi dan memberikan kemudahan dalam merencanakan atraksi dan festival budaya secara hermanen setiap tahun. Festival tari, lagu, lawak, peristiwa peristiwa religius, kompetisi olah raga, festival makanan, festival kostum adalah contoh dari atraksi yang dapat dimasukkan dalam kalender peristiwa.

3. Informasi Pariwisata : Wisatawan pada umumnya hanya mempunyai waktu yang Sangat terbatas. Tetapi biasanya dalam waktu yang terbatas itu mereka ingin melakukan banyak hal. Salah satu jalan untuk memudahkan mereka mencapai sasarannya ialah dengan menyediakan informasi terpadu, informasi yang komplit mengenai kota dengan segala atributnya. Informasi itu dapat diterbitkan dalam bentuk lembaran - lembaran kecil atau leaftlets tetapi lebih penting ialah menerbitkannya dalam sebuah buku kecil. Buku itu memuat informasi tentang berbagai bentuk pelayanan yang ditawarkan kota, macam - macam informasi, calender of events, tempat tempat pariwisata, jeringan transportasi, dll.

4. Kantor Pusat Informasi : Kantor Pusat Informasi pariwisata kota merupakan syarat bagi kota yang ingin memajukan bisnis pariwisatanya. Kantor ini sebaiknya ditempatkan disekitar pusat keramaian dan tidak boleh menampakkan unsur formalitasnya yang dapat membuat orang enggan untuk masuk.

\section{V.2 Element yang terlibat \\ Yang memegang peranan utama} dalam perencanaan pariwisata adalah komponen manusia, orangnya dan masyarakat sekitarnya, baik masyarakat penduduk asli, pemerintah dan pihak swasta. Pemerintah sudah pasti memegang peranan dalam pengembangan pariwisata, dimana telah direncanakan dalam GBHN dan dalam perencanaan kota dalam RTRW atau RDTRK. Selain pemerintah pemegang peranan untuk pengembangan pariwisata adalah pihak swasta. Tanpa partisipasi aktif swasta jelas bahwa tujuan pariwisata tidak akan tercapai, yang dikategorikan dengan unsur swasta dalam pariwisata adalah :

1. Pengusaha Jasa Akomodasi.

2. Pengusaha Biro Perjalanan Wisata.

3. Pengusaha Restoran / Jasa Boga 
4. Pengusaha Objek Wisata

5. Pengusaha Transportasi dan lain - lain.

\section{Kesimpulan}

Sebagai kawasan yang direncanakan mampu memadukan kegiatan komersial dan wisata nudaya, tentunya sangat memungkinkan masuknya pengaruh negative pada kawasan termasuk masyarakatnya. Sehingga sebagai landasan dalam operational dari beberapa panduan yang diusulkan dapat dipergunakan kebijaksanaan di bidang pariwisata, yang meliputi :

1. Peraturan Daerah (perda) bali no. 3 tahun 1991 tentang kebijaksanaan Pariwisata Budaya sebagai landasan dalam pengembangan kepariwisataan di Bali

2. Mengacu pada kebijaksanaan pemda Bali dalam bidang Pariwisata selanjutnya Pemda Kotamadya Denpasar juga menepatkan kebijaksanaan Pariwisata Budaya sebagai landasan Konsepsional.

3. Oleh dinas pariwisata kotamadya daerah tingkat II Denpasar, disebutkan bahwa program pariwisata Budaya mengandung pengertian :

"Jenis kepariwisataan yang dalam perkembangan dan penembangannya menggunakan kebudayaan daerah Bali yang dijiwai oleh agama Hindu yang merupakan bagian dari kebudayaan $\mathrm{Na}$ sional sebagai potensi dasar yang paling dominant, yang didalamnya tersirat saru cita - cita akan adanya hubungan timbale balik antara pariwisata dengan kebudayaan sehingga keduanya meningkat secara serasi, selaras dan seimbang".

Sedangkan dalam pelaksanaannya pariwisata budaya (urban heritage tourism) mengandung pengertian dan konsekuensi sebagai berikut :

1. Urban heritage tourism mengandung pengertian menonjolkan daya trik pokok yang khas yaitu budaya itu sendiri sebagai karunia Tuhan yang tiada bandingnya tanpa melupakan daya tarik yang lain seperti keindahan alam tata kehidupan dan keramah-tamahan penduduknya.

2. Urban heritage tourism mengandung pembatasan yang tegas bahwa segala sesuatu yang bertentangan, merusak maupun merosotkan nilai - nilai budi nurani budaya yang luhur harus dilarang.

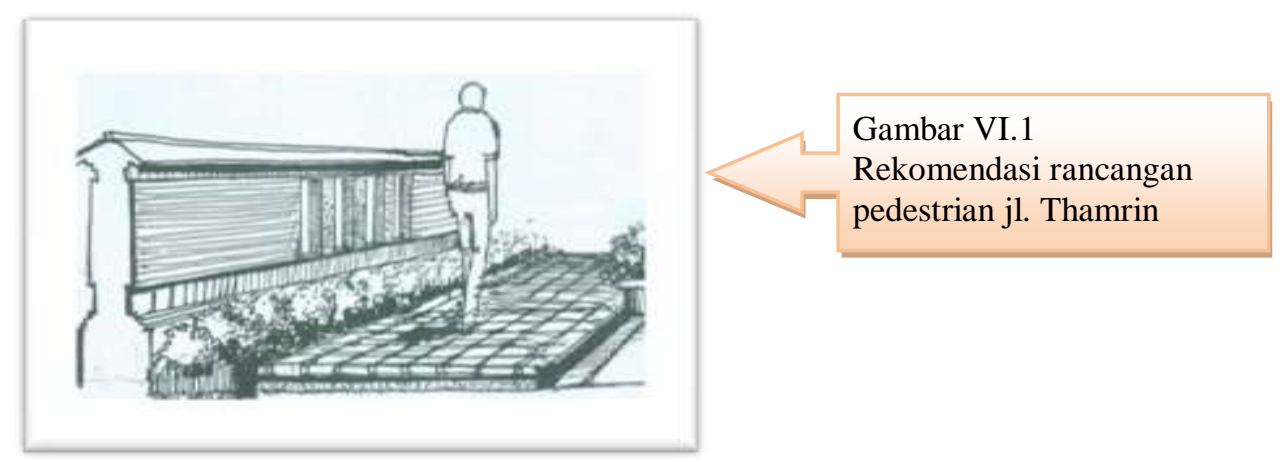

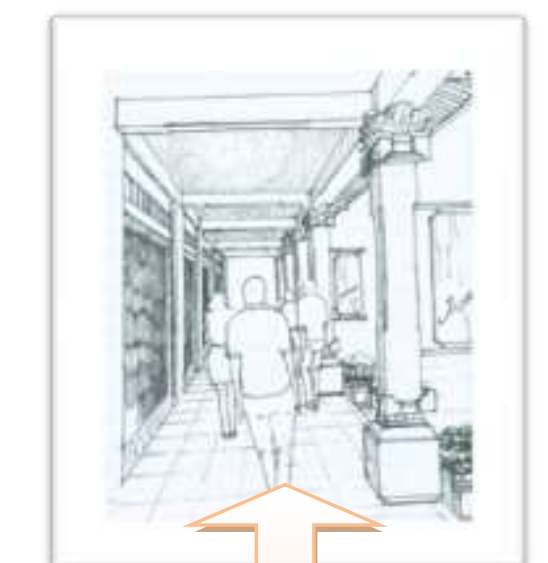

Gambar VI. 2

Rekomendasi rancangan pedestrian di daerah pertokoan

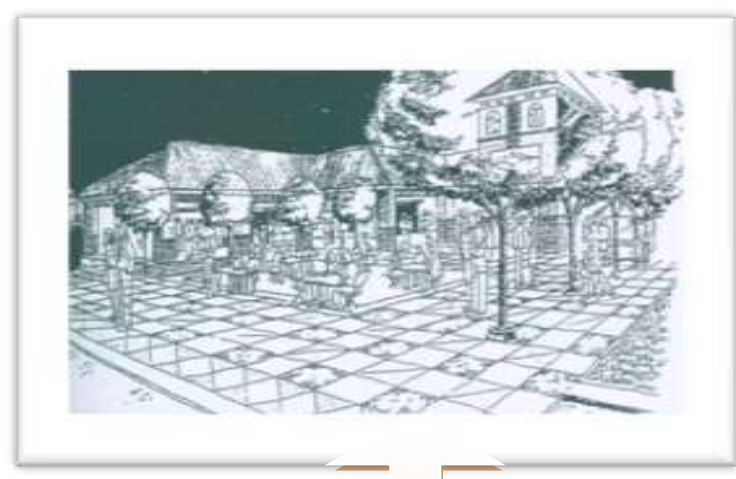

Gambar VI.3

Rekomendasi rancangan open space kawasan persimpangan jl. Thamrin dgn jl. G. Merapi 


\section{DAFTAR PUSTAKA}

Bappeda Kodya Dati II Denpasar (2006), Rencana Detail Tata Ruang Pusat Kota Madya Daerah Tingkat II Denpasar di Kecamatan Denpasar Barat dan Denpasar Timur Tahun 1996/1997 2006/2007 Denpasar

Catannesse Anthony J and James C Synder (1989) Urban Planning (perencanaan Kota), Erlangga Jakarta

Danisworo Mohammad (1980) Konseptualisasi Gagasan dan Upaya Penanganan Proyek Peremajaan Kota Pembangunan Kembali (redevelopment) sebagai focus Jurusan Arsitektur ITB Bandung

Departemen Pendidikan dan Kebudayaan Propinsi Bali (1985) Arsitektur Tradisional Daerah Bali Denpasar

Dinas Tata Kota Pemda Kodya Dati II Denpasar (2006) Informasi Tata Ruang, Proyek Pembinaan dan Permasyarakatan Tata Ruang di Kecamatan Denpasar Barat, Denpasar Timur dan Denpasar Selatan

Gallion Athur B dan Simon Eisner (1983) The Urban - City Planning and Design Van Nostrand Company Inc New Jersey

Lynch Kevin (1960) The Image of The City Massachusetts Institute of Tchnology Cambridge Massachuseets and London

Shirvani Hamid (1985) The Urban Design Prosses Van Nostrand Reinhold Company New York.

Suryabrata, Sumadi [1983], Metodologi Penelitian, Universitas Gajah Mada, Yogyakarta. 